\title{
Cultural Dialectics With Catholic Education in The Border Areas in Sanggau Regency, West Kalimantan
}

\author{
Kristianus ${ }^{1}$, Magdalena ${ }^{2}$, Carolina Lala ${ }^{3}$ \\ 1,2,3 Pontianak State Catholic College, West Kalimantan, Indonesia \\ kㅏistianusatok@gmail.com, ${ }^{2}$ magdalenalina55@gmail.com, ${ }^{3}$ onalala09@gmail.com
}

\begin{abstract}
Keywords:

Dayak, culture, Catholic Education, Indonesia-Malaysia Border.

This research is backed by the condition of the community located in the border area of Indonesia-Malaysia especially in Entikong subdistrict of Sanggau Regency. As the frontier area of social and cultural life of community education in this region has always been a concern especially in conjunction with Malaysian Sarawak. The inhabitants of this region generally embraced Catholicism and Catholic missionaries establishing schools of KINDERGARTEN to high school which are equipped with dormitories. The problem in this study is how the Catholic religious education influences the dialectics of Dayak culture in the region. Data taken using qualitative method is by observation, interviews and living with the community there. The study was held in July-September 2018. The results concluded that the education developed by Catholic missionaries has an effect on the dialectics of Dayak culture in this area. Besides education, other factors also affect the history, politics, and daily life at the border. Another conclusion is that the Catholic missionary (the work of the education that has been developed) has an effect on the identity of Dayak culture in this region, Dayaks are more confident. This could be so because Catholic missionaries appreciate Dayak culture. It is clear that the education developed by the Catholic religion plays a role in the formation of basic and primary materials for the formation of Dayak cultural dialectics in Entikong and other border areas in West Kalimantan.
\end{abstract}

\section{A. INTRODUCTION}

The Dayak experienced a cultural dialectic as the impact of the education they received. This dialectic occurs because the inclusion of modern religion is both Catholic, Christian and Islamic. Islamic religion has even changed the identity of this tribe to Malay (Yusriadi \& Yusriadi, 2014). Ethnicity in West Kalimantan is considered a number of people are strange and ambiguous.

In the beginning, Dayaks came from large groups, but because of the geographic and demographic processes that lasted over a thousand years the group became fragmented. Dayak Tribe of Sukubangsa has similarities and similarities, especially culture. In West Kalimantan, Dayak sub-tribe is very much, and is united by their respective cultures, languages and traditions. Each other may not understand each other, but they have keimiripan especially in terms of culture, and it is estimated they have the same origin that is derived from the same 
ancestors. Most of them inhabit the areas along the river and live from planting rice in the fields (Fox \& Atok, 1997).

Dayak people who are mostly residing in the inland area, life can be said to be traditional, with the traits of agro-cultural life. The latest developments with resettlement programs for indigenous peoples conducted by the Government (through the social department) and the opening of the road that connects several districts, and the rupture of districts into several districts, then open isolation for the Dayak, in turn they open up to the development of the outside and modern life laden with information and technology. If the river was used as a transportation route, the highway is now one of the more effective transportation alternatives. In certain areas the life of Dayak people is now no different from the life of other ethnic (Gotter, 2008).

Indonesia is an archipelago inhabited by a wide variety of nationalities and ethnic groups. This is a situation that causes Indonesia to have various ethnic groups. Based on the data, Indonesian people have about 300 ethnic groups who have their own cultural identity or are called multi ethnic. Ethnic and sub-ethnic Indonesians amounted to 1,000 ethnic and sub-ethnic (Suparlan, 2014). The number of ethnic groups in Indonesia has now grown to one with the Chinese being admitted as one of the ethnic groups in Indonesia (Suparlan, 2003).

In spite of the various Carut Marut issues above, one thing is certain that the Dayak culture today is different from the Dayak culture in the past. The struggles of the various factors faced by Dayak man have created what is called as a dialectic of Dayak culture. The Catholic religion adopted by Dayaks became an important agent in the creation of this dialectic (Kristianus, 2017).

\section{B. METHODS}

This research was conducted by following the working principle of analytical descriptive research and qualitative design. Data is taken based on observations, interviews and direct experience of people's lives (Ruhyat, 2013).

This research will certainly pay attention to the principles of qualitative research work, for example, as can be sought as a natural set of analyses, inductive analysis, researchers as instruments, the boundaries of research, and others.

The research subject is Dayak community in Entikong subdistrict, Sekayam, Beduai and Kembayan of Sanggau regency. Respondents who interviewed 30 people, namely 20 indigenous figures, 5 non-Dayak people, 1 bureaucrat, 1 politician, and 3 religious figures.

Instruments are tools to capture data. So the instrument is closely related to the technique of obtaining data. There are 4 data collection techniques used in this research (Moleong, 2000): (1) observation, (2) interview, (3) questionary, and (4) dokumentation. While Sugiyono (Efianingrum, 2010) Mentioned there are 6 (1) tests, (2) interviews and Kuestioner, (3) inventory listings, (4) Measurement scales, (5) observations, and (6) sociometry.

\section{RESULT AND DISCUSSION}

\section{The influence of education on Dayak culture}

Before the Dutch colonialism occupied this district, it was a colony of the Muslim Sultanate of Brunei. The families of the Sultan who became the ruler (later called the King) lived in the small town of the river estuary located on the West Coast. At this time the Dayak education is 
still very backward. Nevertheless, the Sultanate did not succeed to effectively for Dayak West Kalimantan Islamization (Santy, 2017).

The event was important to see, first, the acceptance of religious from the outside by the people of West Kalimantan, depending on the relationship of mutual respect between the Propagbar and the recipient of religion. This relationship is very normal. Secondly, it is not mentioned in the reason why many West Borneo people embraced Christianity.

It is also worth noting that behind the failure of the Sultanate there was a reason for the advancement of civilization that was armed between the West Kalimantan people who could not read the writing at all (the influence of education). Thirdly, the point of thought is not contrary to the fact that since the past until now there are enough people of Islam in West Kalimantan. In the prior analysis, the community of Muslims in West Kalimantan came from outside.

In Sanggau district generally, the attention of parents gave their children the opportunity to continue school. The high attention of parents to children's education is very related to the availability of educational facilities and infrastructure and the increasing income they earn after becoming a plasma farmer. The availability of educational facilities and infrastructure from elementary School (SD) to high School (SMA) in their area is a condition that makes it easy for them to attend school. The narrative of one of the informant, the jinting (60 years) states that:

I live in this area from birth and I mate also with the one who is still a village, from the marriage I was the gift of 4 people 2 men and 2 female people. Children are the oldest men and the two women. The oldest and second child has been following elementary school education, the elderly only until class III (three) while the second to class V (five), ceased due to economic limitations at that time so that more helps work in the fields or Menoreh rubber. The presence of the oil palm PIR-Bun project by participating into a plasma farmer the results obtained quite moderately. Now my third child (male) has finished his lecture at the FKIP University of Tanjungpura Pontianak and has been working as a civil servant (teacher) in Sanggau State Junior High School, my second child (woman) is graduating from SMA and now has been working as a staff on the research and development of oil palm in the Sintang Palm PEAR-Bun project.

The high attention of parents to the education of family members is because of the assumption that to occupy a place of view in society must be pursued through education. Strictly speaking is a change in education, both economically and quantitatively regarding economic growth in society, as the Peaslee suggests that education helps to destroy traditional perspectives on production and distribution of goods gives a wider view, including knowledge of rational approaches and knowledge of economics, demonstrates ways to organize the economy, and stimulates economic growth (although it can also be a barrier when the development is too fast). Did..... That education is a tool of social change, because it requires a change of attitudes and views. This change can only be done by education because education is a social engineering or agent of social change.

At the research site, after graduating from high school in the Sub-district capital, many of the Dayak children who went to universities in Pontianak and Java (Yogyakarta and Malang). Currently (still in the study in Pontianak and Java) There are about 30 people, both who learn public and private universities. Of that amount has already been completed, and it works well on the company PIR-Bun as well as on the government. As stated by one of the informant whose son is educated scholar and now a civil servant, write (63) stating that: 
My son who was number three so graduated from high school in Sanggau, participated in the college entrance test in Pontianak, at the Faculty of Kegurunan and Science Education (FKIP) Tanjungpura University and finished in 1995 (while showing the researchers some photos graduation of his son and Mr. Tulis and his wife displayed on one of his room walls) and now my son has been working as a civil servant to SMP teachers in Sanggau city, and lived in Sanggau.

The magnitude of the children of Dayak to continue to the higher level of education at the site of research is more than the rapid development of the development of school buildings in their village as well as their parents ' income is increasing also they think that by having a high education will be able to change the social status. Based on the results of great research (Hartoyo, 2012) Conducted in the border area of West Kalimantan, saw that the change in the view of the inland community, especially in the education sector, is closely related to their perception of education itself which they place as important in their lives.

Thus, one can achieve a higher social position than ever when they succeed in achieving economic and educational success, which means that advances in economics will have implications for changing social status. It is in line with research ("Pemerataan Kesempatan Memperoleh Pendidikan Tingkat SLTP di Daerah Perbatasan Kalbar-Malaysia," 2004) That within certain boundaries there is a change in social status due to works and achievements. A person's Status and position can increase because of work and hard work. This means that after the presence of the oil palm PIR-Bun project, the surrounding Dayak community is developing a climate strong competition in achieving the status and position of one based on the works and achievements achieved. It is relevant to the theory of self-efficacy ("Efikasi Diri: Tinjauan Teori Albert Bandura," 2016) and achievement theory (Slameto, 2003) That pertinated motives are formed because of internalizing the values of courage and challenge.

Thus the presence of Catholic religious education has caused social change, mainly on social status as a result of education, as said by Muawanah (Muawanah, 2015), Stating that social status can be expressed as a form of economic power and non-economic power that form can be work, the ability to buy the type of consumer goods and education level.

Dayak people in this district have a low level of education. In the village of Sontas for example, a new one went on to graduate education in the year 1984. Previously only able to high school only. The most popular Dayak person from this education is related to the development pattern that ORBA applied.

The top down and centralistic development pattern of the new order with the discriminatory service system has caused a great impact on rural community education. Directly and indirectly the existence of government policies have turned off the creativity and initiative of local communities. Development programs that are applied create a community dependency. Economic and political domination of certain circles or groups led to prolonged poverty in rural areas. To simply survive the society is not in the opportunity to be independent and autonomous, but by giving a large space for the community will be able to make local initiatives to build themselves, the family to its community and social interaction with the urban population. In the era of Reformasipun seems to have not intentions towards it.

The above development paradigm has caused many social problems, including human trafficking. Government (see: Bureaucracy related to employment) that should serve the people instead. They often conduct extortion practices, intimidating and corruption to achieve their wishes by the name of the rule of law in particular constraints. This includes the 
handling of trafficking cases in West Kalimantan by the government, which has been only Kasustik and Isidentil does not come to their basic issues. Impressed that the existence of trafficking has become a separate land for certain officials (A'ing, 2015).

West Kalimantan Province is one of the provinces that is directly adjacent to the Malaysian state, especially cats. One of the regencies that exports many overseas workers (Malaysia, Singapore and Brunei Darussalam) is Sanggau regency. Over 300,000 thousand Sanggau residents were very dependent on farming. Other businesses, other than agricultural sectors, still lack the number of job seekers. So that local residents choose to work out of the country, both legal and illegal. The results that are in the work out of the country can be seen physically both in the form of parents ' home builders and to help family education. But the kind of work done out of the country is not so obvious.

The need and economic urges ultimately force the Dayak to improve the quality of its human resources. Low HR conditions today have led to the mobility of workers unskilled abroad and forcing them to abandon their birthland. This opportunity is an opportunity for labor agents who do lie or fraud to job seekers, so that the workplace for women whose HR is low is working in a place that is not feasible and in accordance with the promises, such as prostitution or forced labor with unworthy wages.

\section{Influence of the Catholic Church}

In West Kalimantan, generally and especially in the district of Entikong, the Catholic Church plays a role in the formation of basic and primary materials for the establishment of Dayak identity. All the respondents interviewed said this. Missionaries use the opportunity by observing all opportunities to cultivate and christianise communities in this area. It can be said that Catholicism has caused Dayak culture. As a result all Dayak cultural activities are always carried out with Catholic prayers in advance (Kristianus, 2017).

The story of the Catholic religious influence on this Dayak cultural dialectics, commencing from 1890 a small Stasi was opened in Semitau, where it was soon followed by the founding of a church-school combination near Sejiram. Minimal institutional support demands steadfastness at this early stage. New in 1905 where the Capuchin congregation gained official assignments from the Catholic Church Center in Rome with the help of exclusive access to West Kalimantan, then the missionary effort was gaining momentum. The education that missionaries do not only produces the basis for the emergence of a shared identity. It also helps to change to a political consciousness.

\section{CONCLUSION AND SUGGESTIONS}

The conclusions obtained based on the results of the study are as follows: First, the dialectics of the Dayak culture is influenced by the elements of Catholic religious education, history, politics, daily life in the Catholic community and religion which is largely embraced by the border community. The current Dayak culture has been a commodification of the influence, and even the Dayak culture was baptized by Catholicism. The strengthened culture at the bottom level is a culture that has been animated by Catholic teachings, demikianpun the cultural identity of Bidayuh and other Dayak.

Secondly, it was concluded that the Catholic missionary (the work of the education that developed) was very influential in the dialectics of Dayak culture in the border area. As a result of this, the Catholic missionary has been able to make the Dayak more confident. This could be 
so because Catholic missionaries appreciate Dayak customary. The percentage of the answer yes by the high respondent strongly describes the high influence of the Catholic missionary to the progress of the Dayak. It is clear that the Catholic Church plays a role in the formation of basic and primary materials for the formation of Dayak cultural dialectics in Entikong Parish and other border areas.

\section{ACKNOWLEDGEMENT}

A big thank you to the Catholic Bimas Religious Department of the Republic of Indonesia who have funded this research

\section{REFERENCES}

A'ing, A. (2015). Studi Tentang Pembangunan Bidang Pendidikan di Daerah Perbatasan Kecamatan Kayan Hulu Kabupaten Malinau. Pemerintahan Integratif.

Efianingrum, A. (2010). Metode Penelitian Kualitatif dan Kuantitatif. Seminar Sosisologi.

Efikasi Diri: Tinjauan Teori Albert Bandura. (2016). Buletin Psikologi. https://doi.org/10.22146/bpsi.11945

Fox, J., \& Atok, K. (1997). Forest-dweller demographics in West Kalimantan, Indonesia. Environmental Conservation. https://doi.org/10.1017/S0376892997000076

Gotter, U. (2008). Cultural differences and cross-cultural contact: Greek and Roman concepts of power. Harvard Studies in Classical Philology, 104, 179-230.

Hartoyo, A. (2012). Eksplorasi Etnomatematika pada Budaya Masyarakat Dayak Perbatasan IndonesiaMalaysia Kabupaten Sanggau Kalbar. Jurnal Penelitian Pendidikan.

Kristianus. (2017). Dialektika Budaya Dayak: Inkulturasi Agama Katolik dengan Budaya Dayak Kayaan. Juli Jurnal Studi Kultural, $2(2), \quad$ 85-91. https://www.academia.edu/33620056/Dialektika_Budaya_Dayak_Inkulturasi_Agama_Katolik_deng an_Budaya_Dayak_Kayaan

Moleong, L. J. P. D. M. A. (2000). (2000). Metode Penelitian. Penelitian. https://doi.org/10.1021/ol7029646

Muawanah, S. (2015). Nasionalisme Melalui Pendidikan Agama Pada Peserta Didik Sma/Smk/Ma Di Wilayah Perbatasan Kalimantan Barat. SMART. https://doi.org/10.18784/smart.v1i2.247

Pemerataan Kesempatan Memperoleh Pendidikan Tingkat SLTP di Daerah Perbatasan Kalbar-Malaysia. (2004). Jurnal Penelitian Dan Evaluasi Pendidikan. https://doi.org/10.21831/pep.v1i1.2108

Putranto, C. (2015). Menggali Metode Berteologi Pastoral dari Pentalogi R. Hardawiryana SJ. DISKURSUS JURNAL FILSAFAT DAN TEOLOGI STF DRIYARKARA. https://doi.org/10.26551/diskursus.v14i2.25

Roberts, J. (2004). The dialectic of enlightenment. In The Cambridge Companion to: Critical Theory. https://doi.org/10.1017/CCOL0521816602.004

Ruhyat, H. (2013). Metode Penelitian Pendidikan Pendekatan Kuantitaif, Kualitatif, dan R\&D. In Metode Penelitian Pendidikan Pendekatan Kuantitaif, Kualitatif, dan $R \& D$ (pp. 283-393). https://doi.org/10.1007/s13398-014-0173-7.2

Santy, M. B. (2017). Kearifan lokal dalam budaya daerah kalimantan barat (etnis melayu dan dayak). Jurnal Penelitian IPTEKS. https://doi.org/10.32528/ipteks.v2i1.564

Slameto. (2003). Prestasi Belajar. Journal of Education. https://doi.org/10.1016/j.jfineco.2008.10.007

Suparlan, P. (2003). Kesukubangsaan dan Posisi Orang Cina dalam Masyarakat Majemuk Indonesia. Antropologi Indonesia, 71, 23-33.

Suparlan, P. (2014). Bhinneka Tunggal Ika: Keanekaragaman Sukubangsa atau Kebudayaan? Antropologi Indonesia. https://doi.org/10.7454/ai.v0i72.3472

Yusriadi, Y., \& Yusriadi, Y. (2014). Sejarah dan Perkembangan Orang Melayu di Riam Panjang Kalimantan Barat. Khatulistiwa. https://doi.org/10.24260/khatulistiwa.v4i2.257 